\title{
POTENSI Trichoderma spp. DALAM PENGENDALIAN PENYAKIT HAWAR PELEPAH PADI (Rhizoctonia solani) SECARA IN VIVO
}

\section{POTENCY OF Trichoderma spp. TO CONTROL SHEAT BLIGHT DISEASE (Rhizoctonia solani) IN VIVO}

\author{
Resti Fajarfika* \\ Program Studi Agroteknologi Fakultas Pertanian Universitas Garut \\ Jl. Raya Samarang No.52A, Garut, Jawa Barat 44151 \\ *Email:fajarfikaresti@gmail.com
}

\begin{abstract}
The purpose of the study was to determine the ability and effective application time of Trichoderma spp. in reducing sheat blight disease (Rhizoctonia solani) in vivo. Research was arranged in a completely randomized design (CRD) factorial, there are Trichoderma spp. (control, isolate of KP1, KP2, KP3, KA1, $K B 2, W B 1, B A 2)$ and application time (before and after of patogen application), consisting of 16 treatments, each the treatments of 6 plant and 2 replications. The results showed that 7 isolate of Trichoderma spp. and time application (before and after application of pathogen) effective to suppress the sheat blight disease in vivo. Trichoderma spp. could delay infection and symptomps emergence of sheat blight disease.
\end{abstract}

Keywords: Rhizoctonia, Rice, Trichoderma spp.

\begin{abstract}
ABSTRAK
Penelitian bertujuan untuk mengetahui kemampuan dan waktu aplikasi Trichoderma spp. yang efektif dalam menekan penyakit hawar pelepah padi (Rhizoctonia solani) secara in vivo. Penelitian menggunakan Rancangan Acak Lengkap (RAL) factorial yaitu P : Trichoderma spp. (kontrol, isolat KP1, KP2. KP3, KA1, KB2, WB1, BA2) dan T : waktu aplikasi (sebelum dan sesudah aplikasi patogen), sehingga terdapat 16 perlakuan dan masing-masing perlakuan 6 tanaman yang diulang sebanyak 2 kali. Hasil penelitian menunjukkan bahwa 7 isolat Trichoderma spp. dan waktu aplikasi (setelah dan sebelum aplikasi patogen) mampu menekan penyakit hawar pelepah padise cara in vivo. Inokulasi Trichoderma spp. Dapat memperlambat munculnya gejala dan infeksi penyakit hawar pelepah padi.
\end{abstract}

Kata kunci : Padi, Rhizoctonia, Trichoderma spp. 


\section{PENDAHULUAN}

Padi merupakan salah satu komoditas pangan utama yang memiliki peranan penting dalam meningkatkan pendapatan dan tarafhiduppetani, sertauntukmemenuhi kebutuhan pokok karbohidrat bagi penduduk Indonesia. Salah satu kendala dalam usahabu didaya padi adalah penyakit hawar pelepah yang disebabkan oleh Rhizoctonia solani. Menurut Priyatmojo (2006) bahwa $R$. solani yang menyerang tanaman padi termasuk anastomosis group 1 (AG-1), salah satu dari 14 kelompok anastomosis yang ada saat ini. Tanaman yang terserang penyakit ini menunjukkan gejala berupa bercak pada pelepah daun terutama terdapat pada selubung daun. Bila kondisi lembab bercak tersebut dapatterjadi di daun. Bercak tampak coklat kemerahan menjadi putih kelabu dengan pinggiran berwarna coklat. Bercak berbentuk bulat lonjong dan akhirnya menyebar secara meluas. Ukuran bercak dapat mencapai panjang 2 sampai $3 \mathrm{~cm}$, pada kondisi yang memungkinkan pelepah daun dapat menjadi busuk sehingga memengaruhi pembentukan biji (bilaserangan terjadi sebelumbulirberisi)danmenyebabkan tanaman mati (Harahap \& Tjahjono, 1992).

Penyakit hawar pelepah menyebabkan tanaman menjadi mudah rebah dan gabah kopong atau tidak berisi. Serangannya dapat terjadi pada awal musim anakan padi sampai musim panen. Menurut Inagaki (2001), kehilangan hasil padi akibat gangguan penyakit hawar pelepah rata-rata di beberapa negara penghasil beras dunia berkisar 20 sampai 35\%. Kehilangan hasil padi akibat gangguan penyakit hawar pelepah di Indonesia sebesar 20\%, dan pada keparahan penyakit di atas 25\% kehilangan hasil bertambah 4\% untuk tiap kenaikan 10\% keparahan (Suparyono dan Sudir, 1999).

Rhizoctonia solani dapat bertahan hidup pada tanaman hidup atau sebagai saprofit pada sisa-sisa bahan organik. $R$. solani dikenal sebagai patogen yang dapat bertahan hidup di dalam tanah (soil-borne) dalam bentuk sklerotia atau miselia istirahat. Ketika kondisi mendukung perkembangbiakan penyakit, sklerotia dari $R$. solani mampu berinteraksi dengan tanaman inang. Bila pathogen tersebut berhasil masuk ke dalam jaringan tanaman inang dan berkembangbiak akan menyebabkan proses fisiologi tanaman inang terganggu (Agrios, 2005). R. solani memiliki inang yang luas diantaranya jagung dan kacang-kacangan, serta rumput-rumputan sebagai inang alternatif(Hiddink et al., 2005), sehingga pathogen ini sulit dikendalikan karena sumber inokulum tersedia di lahan pertanian sepanjang musim.

Upaya menghindari kerugian dan kegagalan panen yang disebabkan oleh pathogen tersebut petani biasanya menggunakan fungisida sintetik pada waktu menjelang pascapanen. Fungisida sintetik merupakan bahan kimia buatan yang digunakan untuk menghentikan perkembangbiakan jamur pada tanaman. Namun, penggunaan pestisida yang tidak terkontrol dan dilakukan secara terus-menerus mengakibatkan terjadinya resistensi, musnahnya beberapa organisme yang bermanfaat, dan mengakibatkan polusi terhadap lingkungan. Sehingga perlu ada upaya untuk mengurangi penggunaan pestisida dan alternatif pengendalian patogen yang aman terhadap lingkungan, salah satunya menggunakan pengendalian hayati seperti Trichoderma spp. 
Penelitian ini dilakukan karena adanya penelitian pendahuluan yaitu eksplorasi jamur antagonis Trichoderma spp. di daerah Garut yang menghasilkan 7 isolat dan pengujiannya skala laboratorium terhadap R.solani. Namun, kemampuan antagonis tersebut belum diketahui dalam skala rumah kaca. Penelitian ini bertujuan untuk mengetahui kemampuan dan waktu aplikasi Trichoderma spp. yang efektifdalam menekan penyakit hawar pelepah padi (Rhizoctonia solani) secara in vivo.

\section{BAHAN DAN METODE}

Penelitian dilaksanakan di Laboratorium dan Rumah Kaca Fakultas Pertanian, Universitas Garut pada Bulan Mei sampai Juli 2019. Bahan yang digunakan adalah tujuh isolate Trichoderma spp. Hasil eksplorasi dari daerah Garut (KP1, KP2, KP3, KA1, $\mathrm{KB} 2, \mathrm{BA} 2$ ), isolate pathogen Rizoctonia solani koleksi Laboratorium Fitopatologi Balai Besar Peramalan Organisme Pengganggu Tanaman (BBPOPT) Karawang, alkohol 70\%, aquades, media Potato Dextrose Agar (PDA), benih padi varietas Ciherang, pupuk urea, $\mathrm{KCl}$ dan SP-36. Alat-alat yang digunakan pada percobaan ini adalah cawan petri, gelas piala, gelas ukur, autoklaf, laminar air flow, timbangan elektrik, nampan plastik, polybag, jarum ose, bunsen, alumunium foil, dan plastik tahan panas.

Penelitian menggunakan Rancangan Acak Lengkap (RAL) terdiri atas 16 perlakuan, setiap perlakuan terdapat 6 tanaman dan 2 ulangan, sehingga ada 192 tanaman. Data keparahan penyakit yang diperoleh dianalisis dengan sidik ragam (Anova), jika terdapat beda nyata maka analisis lanjutannya menggunakan Jarak Berganda Duncan's pada taraf kesalahan 5\%.

\section{Inokulasi Trichoderma spp. dan Rhizoctonia solani pada benih padi}

Pengujian dilakukan menurut Hidayat et al., (2014) dengan sedikit modifikasi, tahapan perlakuan sebelum aplikasi pathogen $R$. solani yaitu (1) Perendaman benih padi dalam suspense konidia Trichoderma spp. (control menggunakan akuades) selama 24 jam, (2) Benih padi dikeringanginkan selama 10-15 menit, (3) Perendaman benih padi dalam suspense konidia $R$. solani selama 24 jam, (4) Benih padi dikeringanginkan selama 10-15 menit, (5) Benih padi disemaikan dalam nampan selama 14 hari, (6) Benih padi dipindah tanam ke polybag, (7) Tanaman padi yang berumur 2 minggu setelah tanam, disemprot dengan suspense konidia Trichoderma spp. sebanyak $500 \mathrm{ml}$ (control tanpa Trichoderma spp.), (8) Setelah 24 jam, pelepah padi dilukai dan disemprot R.solani sebanyak $500 \mathrm{ml}$, diamati setiap minggu selama 3 minggu.

Tahapan perlakuan setelah aplikasi pathogen $R$. solani yaitu (1) Perendaman benih padi dalam suspense konidia R. solani selama 24 jam, (2) Benih padi dikeringanginkan selama 10-15 menit, (3) Perendaman benih padi dalam suspense konidia Trichoderma spp. selama 24 jam (control tanpa Trichoderma spp.), (4) Benih padi dikeringanginkan selama 10-15 menit, (5) Benih padi disemaikan dalam nampan selama 14 hari, (6) Benih padi dipindahtanam ke polybag, (7) Tanamanpadi yang berumur 2 minggu setelah tanam, pelepah padi dilukai dan disemprot dengan suspense konidia R. solani sebanyak $500 \mathrm{ml}$, 
(8) Setelah 24 jam, tanaman padi disemprot Trichoderma spp. sebanyak $500 \mathrm{ml}$ (control tanpa Trichoderma spp.), diamati setiap minggu selama 4 minggu.

Variabel pengamatan meliputi masa inkubasi, keparahan penyakit berdasarkan skoring, tinggi tanaman, jumlah anakan/rumpun, dan jumlah daun. Keparahan penyakit hawar pelepah dilakukan terhadap tanaman padi dari saat benih mulai tumbuh hingga menunjukkan gejala penyakit. Keparahan penyakit dihitung menggunakan rumus sebagai berikut (Dirjen Pertanian Tanaman Pangan, 2003).

$$
I=\frac{\sum(\text { ni } x \text { vi) }}{N . V} \times 100 \%
$$

Keterangan :

I $=$ Intensitas Serangan

ni = Jumlah Tanaman berdasarkan Skala Kerusakan vi

vi = Nilai Skala Kerusakan Contoh ke-i

$\mathrm{N}=$ Jumlah Tanaman yang Diamati

$\mathrm{V}=$ Nilai Skala KerusakanTertinggi Skoring skala kerusakan tanaman sebagai berikut. $0=$ Tanaman sehat

$1=1-20 \%$ bagian tanaman yang terinfeksi

$2=21-40 \%$ bagian tanaman yang terinfeksi

$3=41-60 \%$ bagian tanaman yang terinfeksi

$4=61-80 \%$ bagian tanaman yang terinfeksi

$5=81-100 \%$ bagian tanaman yang terinfeksi

\section{HASIL DAN PEMBAHASAN}

Pengaruh Trichoderma spp. terhadap Masa

\section{Inkubasi Patogen}

Masa inkubasi merupakan waktu yang diperlukan oleh pathogen darimulai inokulasi untuk berlipat ganda hingga menimbulkan gejala pada inangnya. Berdasarkan hasil pengamatan, masa inkubasi atau kemunculan gejala penyakit pelepah padi terjadi pada 2 minggu setelah aplikasi penyemprotan atau pada 4 minggu setelah tanam (25-30 hari), satu minggu lebih lambat dibandingkan dengan tanaman yang tidak diinokulasi Trichoderma spp. (muncul gejala pada 3 MST). Hal ini berarti inokulasi Trichoderma spp. pada tanaman padi dapat menunda munculnya infeksi Rhizoctonia solani. Penundaan kemunculan gejala mampu menurunkan intensitas penyakit. Hal tersebut terjadi diduga karena berlangsungnya persaingan antara pathogen dengan antagonis Trichoderma spp, sehingga pathogen membutuhkan waktu lebih lama untuk menginfeksi tanaman dan munculnya gejala. Hal ini sesuai dengan pendapat Widodo (1993), bahwa pathogen sukar melakukan penetrasi ke tanaman dan menimbulkan penyakit apabila system perakaran terkuasai agen antagonis.

Apabila masa inkubasi pada perlakuan kontrol (tanpa Trichoderma spp.) dibandingkan dengan penelitian Muslim dkk. (2012), inkubasi tanaman padi berkisar 4-6 hari setelah aplikasi, maka terdapat perbedaan yang cukup jauh. Hal ini diduga bahwa varietas memengaruhi ketahanan terhadap patogen. Menurut Muslim dkk. (2012) bahwa varietas Ciherang tergolong varietas agak tahan terhadap Rhizoctonia solani. Selain itu, masa inkubasi dapat berbeda karena tingkat virulensi patogen. Menurut Agrios (1998) bahwa virulensi pathogen dapat hilang dalam biakan atau inang akibat dari seleksi individu dari strain patogen yang kurang virulen.

Tanaman padi yang terserang menunjukkan gejala terdapat bercak berwarna coklat pada pelepah padi (Gambar 1). Menurut Gallagher (1991) bahwa gejala penyakit terjadi mulai dari pangkal batang 


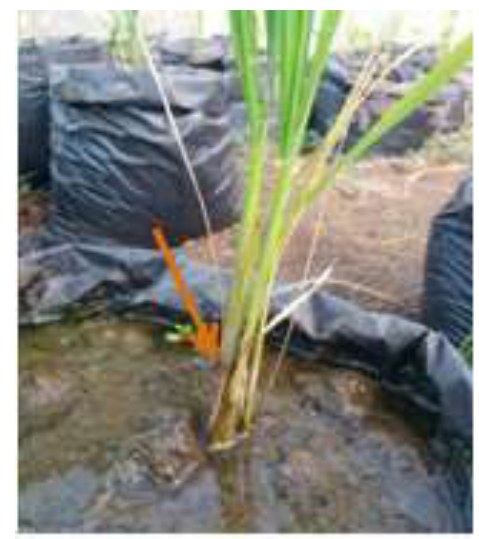

Gambar 1. Gejala serangan Rhizoctonia solani

tanaman pada atas permukaan air di mana mulai terjadi infeksi. Beberapa kasus, seluruh tanaman akan berubah menjadi kering dan berwarna kecoklatan. Penyakit berkembang mulai dari pangkal tanaman hingga tajuk yang saling menutup. Setelah tajuk saling menutup, dengan kelembaban serta kelebatan rumpun meningkat kemudian infeksi jamur meluas ke bagian atas tanaman dan menyebabkan penyakit tersebut tampak parah hanya pada pelepah daun sesudah tanaman hamper membentuk bulir dan selanjutnya penyakit berkembang secara cepat. Perkembangan penyakit hawar pelepah padi adalah hasil interaksi antara populasi inokulum awal jamur R. solani, ketahanan tanaman padi, dan daya dukung lingkungan (Nuryanto et al., 2011).

\section{Pengaruh Trichoderma spp. terhadap Intensitas Penyakit}

Hasil analisis ragam menunjukkan bahwa Trichoderma spp. dapat menurunkan tingkat intensitas penyakit hawar pelapah padi baik sebelum maupun setelah aplikasi pathogen Rhizoctonia solani (Tabel 1). Rerata intensitas serangan mulai pada minggu ke-4 setelah tanam, yaitu sebesar $4,06-17,22 \%$ dan semakin menurun pada minggu ke-5 dan ke-6 sebesar 4,06-9,79\%. Menurut Groth (2007) bahwa keparahan penyakit hawar pelepah padi tergantung oleh jumlah inokulum awal yang tersedia dan kondisi lingkungan akibat dari manajemen budidaya.

Hasil pengamatan pada umur 4, 5 dan 6 minggu setelah tanam (MST) menunjukkan tanaman yang diberi

Tabel 1. Pengaruh isolat Trichoderma spp. terhadap intensitas penyakit

\begin{tabular}{llcc}
\hline \multicolumn{1}{c}{ Perlakuan } & \multicolumn{3}{c}{ Waktu Pengamatan } \\
\cline { 2 - 4 } & \multicolumn{1}{c}{$4 \mathrm{MST}$} & $5 \mathrm{MST}$ & $6 \mathrm{MST}$ \\
\hline P0t1 = Tanpa Trichoderma, sebelum patogen & $22.53 \mathrm{c}$ & $20.38 \mathrm{~b}$ & $21.84 \mathrm{~b}$ \\
P1t1 = Isolat KP1, sebelum patogen & $7.67 \mathrm{ab}$ & $4.06 \mathrm{a}$ & $4.06 \mathrm{a}$ \\
P2t1 = Isolat KP2, sebelum patogen & $16.57 \mathrm{bc}$ & $7.67 \mathrm{a}$ & $7.67 \mathrm{a}$ \\
P3t1 = Isolat KP3, sebelum patogen & $7.67 \mathrm{ab}$ & $4.06 \mathrm{a}$ & $4.06 \mathrm{a}$ \\
P4t1 = Isolat KA1, sebelum patogen & $7.67 \mathrm{ab}$ & $4.06 \mathrm{a}$ & $4.06 \mathrm{a}$ \\
P5t1 = Isolat KB2, sebelum patogen & $15.10 \mathrm{abc}$ & $7.67 \mathrm{a}$ & $7.67 \mathrm{a}$ \\
P6t1 = Isolat WB1, sebelum patogen & $17.22 \mathrm{bc}$ & $4.06 \mathrm{a}$ & $4.06 \mathrm{a}$ \\
P7t1 = Isolat BA2, sebelum patogen & $4.06 \mathrm{a}$ & $4.06 \mathrm{a}$ & $4.06 \mathrm{a}$ \\
P8t2 = Tanpa Trichoderma, sesudah patogen & $18.92 \mathrm{bc}$ & $20.38 \mathrm{~b}$ & $20.38 \mathrm{~b}$ \\
P9t2 = Isolat KP1, sesudah patogen & $15.53 \mathrm{abc}$ & $7.67 \mathrm{a}$ & $7.67 \mathrm{a}$ \\
P10t2 = Isolat KP2, sesudah patogen & $13.41 \mathrm{abc}$ & $4.06 \mathrm{a}$ & $4.06 \mathrm{a}$ \\
P11t2 = Isolat KP3, sesudah patogen & $4.06 \mathrm{a}$ & $4.06 \mathrm{a}$ & $4.06 \mathrm{a}$ \\
P12t2= Isolat KA1, sesudah patogen & $11.49 \mathrm{abc}$ & $9.79 \mathrm{a}$ & $9.79 \mathrm{a}$ \\
P13t2 = Isolat KB2, sesudah patogen & $18.69 \mathrm{bc}$ & $4.06 \mathrm{a}$ & $4.06 \mathrm{a}$ \\
P14t2= Isolat WB1, sesudah patogen & $7.67 \mathrm{ab}$ & $4.06 \mathrm{a}$ & $4.06 \mathrm{a}$ \\
P15t2= Isolat BA2, sesudah patogen & $4.06 \mathrm{a}$ & $4.06 \mathrm{a}$ & $4.06 \mathrm{a}$ \\
\hline
\end{tabular}

Keterangan : Angka rata-rata pada kolom yang diikuti huruf yang sama tidak berbeda nyata berdasarkan Uji Jarak Berganda Duncan pada taraf $5 \%$. 
perlakuan Trichoderma spp. Berbeda nyata dengan control baik sebelum aplikasi pathogen maupun sesudah aplikasi patogen. Umur 4 MST, terjadi perbedaan persentase intensitas penyakit antar perlakuan. Hal ini memberikan indikasi bahwa kemampuan setiap spesies Trichoderma spp. dalam mengendalikan jamur pathogen berbeda-beda. Perbedaan tersebut diduga karena Trichoderma spp. memiliki kecepatan pertumbuhan yang berbeda tiap spesiesnya. Hal ini didukung oleh Talanca dkk. (1998) dalam Umrah dkk. (2009) menyatakan bahwa mekanisme terjadinya perbedaan kemampuan diantara beberapa stater belum diketahui secara pasti, namun stater yang mempunyai laju partumbuhan cepat, kemungkinan mempunyai antagonis tinggi. Perlakuan yang memberikan penekanan tertinggi terhadap penyakit hawar pelepah padi yaitu Trichoderma spp. isolat $\mathrm{BA} 2$ sebelum aplikasi patogen $(\mathrm{P} 7 \mathrm{t} 1)$, isolat KP3 dan BA2 sesudah aplikasi patogen (P11t2 dan P15t2). Umur 5 dan 6 MST intensitas penyakit tidak berbeda nyata pada semua perlakuan kecuali kontrol, hal ini terjadi karena Trichoderma spp. tumbuh dengan cepat dan mengungguli dalam penguasaan ruang dan nutrisi sehingga pada akhirnya dapat menekan pertumbuhan Rhizoctonia solani. Keadaan tersebut sesuai dengan yang dikemukakan oleh Cook \& Baker (1983) bahwa proses kolonisasi Trichoderma spp. dengan cepat mendahului pathogen kemudian berkompetisi secara agresif atau menyerang tempat yang ditempati patogen. Mekanisme lain penghambatan $R$. solani diduga disebabkan oleh Trichoderma spp. yang bersifat mikoparasit akan menekan populasi cendawan patogen yang sebelumnya mendominasi. Interaksi diawali dengan melilitkan hifanya pada cendawan patogen yang akan membentuk struktur seperti kait yang disebut haustorium dan memarasit cendawan patogen (Papavizas, 1985).

Tabel 2. Pengaruh inokulasi Trichoderma spp. terhadap pertumbuhan tanaman padi

\begin{tabular}{|c|c|c|c|c|c|c|}
\hline \multirow{3}{*}{ Perlakuan } & \multicolumn{6}{|c|}{ Pengamatan pertumbuhan tanaman ke- } \\
\hline & \multicolumn{2}{|c|}{ Tinggi tanaman $(\mathrm{cm})$} & \multicolumn{2}{|c|}{ Jumlah anakan } & \multicolumn{2}{|c|}{$\begin{array}{l}\text { Jumlah daun/ rumpun } \\
\text { (helai) }\end{array}$} \\
\hline & $3 \mathrm{MST}$ & $4 \mathrm{MST}$ & $3 \mathrm{MST}$ & $4 \mathrm{MST}$ & $3 \mathrm{MST}$ & $4 \mathrm{MST}$ \\
\hline P0t1= TanpaTrichoderma, sebelumpatogen & $38.00 \mathrm{a}$ & $59.33 \mathrm{a}$ & $2.83 \mathrm{~b}$ & $4.66 \mathrm{a}$ & $10.67 \mathrm{abc}$ & $14.66 \mathrm{a}$ \\
\hline $\mathrm{P} 1 \mathrm{t} 1=$ Isolat $\mathrm{KP}$, sebelum patogen & $40.45 \mathrm{a}$ & $56.83 \mathrm{a}$ & $1.91 \mathrm{ab}$ & $4.00 \mathrm{a}$ & $7.83 \mathrm{abc}$ & $17.42 \mathrm{a}$ \\
\hline $\mathrm{P} 2 \mathrm{t} 1=$ Isolat KP2, sebelum patogen & $36.46 \mathrm{a}$ & $53.50 \mathrm{a}$ & $2.00 \mathrm{ab}$ & $2.75 \mathrm{a}$ & $5.41 \mathrm{a}$ & $12.00 \mathrm{a}$ \\
\hline P3t1= Isolat KP3, sebelum patogen & $41.62 \mathrm{a}$ & $59.08 \mathrm{a}$ & $2.83 \mathrm{~b}$ & $5.08 \mathrm{a}$ & $12.75 \mathrm{bc}$ & $15.25 \mathrm{a}$ \\
\hline $\mathrm{P} 4 \mathrm{t} 1=$ Isolat $\mathrm{KA} 1$, sebelum patogen & $38.00 \mathrm{a}$ & $54.66 \mathrm{a}$ & $1.75 \mathrm{a}$ & $3.41 \mathrm{a}$ & $6.33 \mathrm{ab}$ & $13.00 \mathrm{a}$ \\
\hline $\mathrm{P} 5 \mathrm{t} 1=$ Isolat $\mathrm{KB} 2$, sebelum patogen & $42.54 \mathrm{a}$ & $57.66 \mathrm{a}$ & $2.08 \mathrm{ab}$ & $2.83 \mathrm{a}$ & $5.50 \mathrm{a}$ & $13.66 \mathrm{a}$ \\
\hline P6t1= Isolat WB1, sebelum patogen & $43.66 \mathrm{a}$ & $58.25 \mathrm{a}$ & $2.00 \mathrm{ab}$ & $3.67 \mathrm{a}$ & $11.91 \mathrm{abc}$ & $15.00 \mathrm{a}$ \\
\hline $\mathrm{P} 7 \mathrm{t} 1=$ Isolat BA2, sebelum patogen & $41.41 \mathrm{a}$ & $59.41 \mathrm{a}$ & $2.50 \mathrm{ab}$ & $3.92 \mathrm{a}$ & $9.08 \mathrm{abc}$ & $15.16 \mathrm{a}$ \\
\hline P8t2= Tanpa Trichoderma, sesudah patogen & $41.67 \mathrm{a}$ & $56.66 \mathrm{a}$ & $2.25 \mathrm{ab}$ & $4.08 \mathrm{a}$ & $7.83 \mathrm{abc}$ & $11.75 \mathrm{a}$ \\
\hline P9t2= Isolat KP1, sesudah patogen & $46.29 \mathrm{a}$ & $59.91 \mathrm{a}$ & $2.67 \mathrm{ab}$ & $3.50 \mathrm{a}$ & $7.41 \mathrm{abc}$ & $14.66 \mathrm{a}$ \\
\hline P10t2= Isolat KP2, sesudah patogen & $40.75 \mathrm{a}$ & $59.83 \mathrm{a}$ & $1.92 \mathrm{ab}$ & $4.00 \mathrm{a}$ & $7.83 \mathrm{abc}$ & $13.58 \mathrm{a}$ \\
\hline P11t2= Isolat KP3, sesudah patogen & $44.54 \mathrm{a}$ & $59.83 \mathrm{a}$ & $2.83 \mathrm{~b}$ & $4.50 \mathrm{a}$ & $8.58 \mathrm{abc}$ & $13.17 \mathrm{a}$ \\
\hline $\mathrm{P} 12 \mathrm{t} 2=$ Isolat KA1, sesudah patogen & $43.45 \mathrm{a}$ & $59.33 \mathrm{a}$ & $2.58 \mathrm{ab}$ & $3.91 \mathrm{a}$ & $10.33 \mathrm{abc}$ & $12.33 \mathrm{a}$ \\
\hline $\mathrm{P} 13 \mathrm{t} 2=$ Isolat KB2, sesudah patogen & $42.92 \mathrm{a}$ & $59.33 \mathrm{a}$ & $2.25 \mathrm{ab}$ & $4.00 \mathrm{a}$ & $8.25 \mathrm{abc}$ & $12.17 \mathrm{a}$ \\
\hline $\mathrm{P} 14 \mathrm{t} 2=$ Isolat $\mathrm{WB} 1$, sesudah patogen & $41.66 \mathrm{a}$ & $57.08 \mathrm{a}$ & $2.75 \mathrm{~b}$ & $4.33 \mathrm{a}$ & $13.50 \mathrm{c}$ & $21.08 \mathrm{a}$ \\
\hline $\mathrm{P} 15 \mathrm{t} 2=$ Isolat BA2, sesudah patogen & $43.16 \mathrm{a}$ & $60.25 \mathrm{a}$ & $2.17 \mathrm{ab}$ & $4.58 \mathrm{a}$ & $10.00 \mathrm{abc}$ & $16.41 \mathrm{a}$ \\
\hline
\end{tabular}

Keterangan : Angka rata-rata pada kolom yang diikuti huruf yang sama tidak berbeda nyata berdasarkan Uji Jarak Berganda Duncan pada taraf 5\%. 
Selain itu, Trichoderma spp. mampu mengeluarkan toksin berupa enzim b-(1,3)- glukanase, kitinase, dan selulase yang dapat menghambat bahkan membunuh patogen (Talancaet al., 1998) danmenghasilkan antibiotic seperti trichodermin dan viridin (Papavizas, 1985).

Periode kritis tanaman padi adalah jika penyakit hawar pelepah padi menyerang padi pada stadia pembentukan anakan maksimum, bunting, berbunga, dan pengisian malai. Namun, pengendalian yang paling tepat dilakukan saat tanaman memasuki stadia pembentukan anakan maksimum untuk menekan kehilangan hasil padi (Milati dan Nuryanto, 2019).

\section{Pengaruh Trichoderma spp.pada Pertumbuhan}

\section{Tanaman}

Pengaruh perlakuan terhadap komponen pertumbuhan padi menunjukkan antar perlakuan tidak berpengaruh terhadap tinggi tanaman baik pada 3 maupun 4 MST (Tabel 2), begitupun pada 5,6, dan 7 MST (Data Tidak dipublikasi) tidak berpengaruh nyata. Perlakuan terhadap jumlah anakan dan jumlah daun/ rumpun berpengaruh pada $3 \mathrm{MST}$, sedangkan pada pengamatan 4 (Tabel 2), 5, 6, dan 7 MST (Data tidak dipublikasi) tidak berpengaruh. Hal ini diduga karena Trichoderma spp. lebih memfokuskan terhadap pengendalian penyakit hawar pelepah padi. Namun, pada setiap pengamatan terjadi peningkatan pertumbuhan tinggi tanaman, jumlah anakan dan jumlah daun. Menurut Wahyu dan Pasetriyani (2006) bahwa Trichoderma spp. berperan besar dalam menjaga kesuburan tanah dan memiliki potensi sebagai "kompos aktif' yang dapat dimanfaatkan untuk meningkatkan dan merangsang pertumbuhan akar, batang, daun, bunga dan memberikan hasil yang lebih baik pada tanaman.

\section{KESIMPULAN}

Tujuh isolate Trichoderma spp. dan waktu aplikasi berpengaruh terhadap penekanan penyakit hawar pelepah padi secara in vivo. Inokulasi Tricoderma spp. dapat memperlambat munculnya gejala dan infeksi penyakit hawar pelepah padi, serta tidak berpengaruh terhadap pertumbuhan tanaman padi.

\section{DAFTAR PUSTAKA}

Agrios, G. N. 1988. Ilmu Penyakit Tumbuhan, edisi ketiga. (Diterjemahkan oleh B. Munsir). Gadjah Mada University Press, Yogyakarta. $713 \mathrm{hlm}$.

Agrios, G.N. 2005. Plant Pathology $5^{\text {th }}$ ed. Elsevier, Amsterdam. 922 p.

Cook, R.J.\& Baker, K.F. 1983. The Nature and Practice of Biological Control of Plant Pathogens. The American Phytopathological Society, St. Paul, Minnesota.

Direktorat Jenderal Pertanian Tanaman Pangan. 2003. Pedoman Pengujian Pestisida Berbahan Aktif Majemuk. Direktorat Jenderal Bina Sarana Pertanian, Jakarta. 76 hal.

Gallagher, P.K. 1991. Thermoanalytical Methods, Materials Science and Technology. Edited by Cahn R.W, Hassen P, Kramer E. J. VCH Publisher. Part 1. Vol 2A. New York.

Groth, D.E. 2007. Effects of cultivar resistance and single fungicide application on rice sheath blight, yield, and quality. J. Crop Protec. 27: 11251130 .

Harahap, I. S. \& Tjahjono, B. 1992. Pengendalian Hama Penyakit Padi. Penebar Swadaya, Jakarta. 114 hal. 
Hiddink, G.A.,Termorshuizen,A.J., Raajimakers, J.M., \& van Bruggen,A.H.C. 2005. Effect of Mixed and Single Crops on Diseases Suppressiveness of Soils. Phytopathology. 95: 1325"1332.

Hidayat, Y.S., Nurdin, M. \& Suskandini. 2014. Penggunaan Trichoderma sp. Sebagai agensia pengendalian terhadap Pyricularia oryzae Cav. Penyebab Blas pada Padi. J. Agrotek Tropika, Vol. 2 (3): 414-419.

Inagaki, K. 2001. Outbreaks of Rice Sclerotium Diseases in Paddy Fields and Physiological and Ecological Characteristics of this Causal Fungi. Science Replications Agricultures, Meijo University. Vol. 37: 57"66.

Milati, L. N. \& Nuryanto, B. 2019. Periode Kritis Pertumbuhan Tanaman Padi terhadap Infeksi Penyakit Hawar Pelepah dan Pengaruhnya terhadap Hasil Gabah. Penelitian Pertanian Tanaman Pangan, Vol.3 (2) : 61-66.

Muslim, A., Permatasari, R., Mazid, A. 2012. Ketahanan beberapa Varietas Padi Rawa Lebak terhadap Penyakit Hawar Upih yang Disebabkan oleh Rhizoctonia solani. Jurnal Lahan Suboptimal, Vol. 1 (2): 163-169.

Nuryanto, B., Priyatmojo, A., Hadisutrisno, B., Sunarminto,B.H.2011. Perkembangan penyakit hawar upih padi (Rhizoctonia solani Kuhn.) di sentra-sentra penghasil padi Jawa Tengah dan Daerah Istimewa Yogyakarta. Jurnal Budidaya Pertanian,Vol.7(1):1-7.

Papavizas, G.G. 1985. Trichoderma and Gliocladium: Biology, ecology and potential for biocontrol. Phytopathol., Vol. 23(1): 23 - 54.
Priyatmojo, A. 2006. Tipe Mating pada Empat Isolat Thanatephorus cucumeris (Anamorf: Rhizoctonia solani) Anastomosis Group (AG) I-1C. Jurnal Perlindungan Tanaman Indonesia, Vol.12 (2): 112"122.

Suparyono \& Sudir. 1999. Peran Sklerotium dan Bentuk Lain Patogen Rhizoctonia solani, sebagai Sumber Inokulum Awal Penyakit Hawar Pelepah Padi. Jurnal Perlindungan Tanaman Indonesia, Vol. 5 (1): 7"12.

Talanca,A.H.,Soenarti ningshih \& Wakman, W. 1998. Daya Hambat Trichoderma sp. pada Beberapa Jenis Jamur Patogen. Prosiding Seminar Ilmiah PEI, PFI dan HPTI Komda Sum-Sel, Maros (5 Desember 1998).

Umrah, T., Anggraeni, R.,Esyanti, R., I Nyoman \& Aryantha, P. 2009. Antagonisitas dan Efektifitas Trichoderma sp. dalam Menekan Perkembangan Phytophthora palmivora pada Buah Kakao. Jurnal Agroland, Vol.16 (1): 9-16.

Wahyu, Y. \& Pasetriyani, E. 2006. Pengaruh Introduksi Jamur Trichoderma spterhadap Perkembangan Penyakit Layu (Fusarium oxysforum), Pertumbuhan dan Hasil TanamanTomat. BPTP Jawa Barat.

Widodo. 1993. Penggunaan Pseudomonas kelompok Fluorescens untuk Mengendalikan Penyakit Akar pada Caisin (Brasica campestris var. chinensis). Tesis. IPB. Bogor. 41 hal. 